\title{
Utilizing benthic foraminifera to explore the environmental condition of the Laizhou Bay (Bohai Sea, China)
}

\author{
Sandra Donnici ${ }^{\text {a, }}$, Rossana Serandrei-Barbero ${ }^{\mathrm{b}}$, Xuelu Gao ${ }^{\mathrm{c}, \mathrm{d}, \mathrm{e}}$, Cheng Tang ${ }^{\mathrm{c}, \mathrm{e}}$, Luigi Tosi ${ }^{\mathrm{a}}$ \\ ${ }^{a}$ National Research Council, Institute of Geosciences and Earth Resources, Via Gradenigo, 6, 35131 Padova, Italy \\ ${ }^{\mathrm{b}}$ Formerly National Research Council - Institute of Marine Sciences, Castello 2737/F, 30122 Venice, Italy \\ ${ }^{\mathrm{c}}$ Chinese Academy of Sciences, Key Laboratory of Coastal Environmental Processes and Ecological Remediation, Yantai Institute of Coastal Zone Research, Yantai, \\ Shandong 264003, China \\ ${ }^{\mathrm{d}}$ University of Chinese Academy of Sciences, Beijing 100049, China \\ ${ }^{\mathrm{e}}$ Chinese Academy of Sciences, Center for Ocean Mega-Science, Qingdao, Shandong 266071, China
}

\section{A R T I C L E I N F O}

\section{Keywords:}

Benthic foraminifera

Foram-AMBI

Foraminiferal biotopes

Laizhou Bay

\begin{abstract}
A B S T R A C T
Through the analysis of benthic foraminifera in the soft bottom sediments of the Laizhou Bay - Yellow River Delta system, this study characterized the foraminiferal biotopes and explored the possibility of obtaining an index of ecological quality comparable with other estuarine and coastal environments of the world. Five foraminiferal biotopes have been identified and their distribution patterns highlight the ecological stress from the marine-fluvial water mixing and pollution. The foraminiferal species were analyzed as a function of organic carbon gradients, and the main species were assigned to four ecological groups based on their sensitivity/ tolerance towards an increasing stress gradient. Finally, the relative proportions of the species assigned to the four different ecological groups were used for the definition of a marine biotic index based on foraminifera, i.e. the Foram-AMBI, and thus the assessment of the ecological quality status of marine soft-bottom habitats.
\end{abstract}

\section{Introduction}

The growing awareness of the loss of ecological value in the estuarine and coastal systems has brought about a continual evaluation of new instruments capable of monitoring marine areas affected by anthropogenic activities. In transitional marine environments, biota takes on the role of environmental indicators and various indices based on biota have been developed (e.g., Borja et al., 2000 and reference therein).

Benthic foraminifera, a class of the kingdom Protista (Loeblich and Tappan, 1987) secreting a test, are commonly used as environmental indicators for the high number of individuals present in the sediments, the high level of specialization and their sensitivity to environmental changes (e.g., Scott et al., 2005; Alve et al., 2009; Serandrei-Barbero et al., 2011). Furthermore, compared with the traditional macrofauna methods requiring large samples and time-consuming analysis, foraminifera can provide information on ecological quality status (EcoQS) even with sampling done for different scopes (chemistry, mineralogy, macrobenthos). Foraminifera are also the best choice (a good alternative) in habitats with low abundance of macroinvertebrates.

Unlike the monitoring based on macroinvertebrate surveys, the large diffusion and microscopic dimensions of benthic foraminifera make foraminiferal biotopes excellent ecological indicators (e.g., Albani et al., 2007). The biotope is an area characterized by uniform physicochemical characteristics in which a species assemblage forming a biocoenosis lives. In marine transitional environments, a large number of species of the unicellular organisms are present with a relatively high number of individuals and with assemblages typical of dominant physicochemical parameters (Alve and Murray, 1999). In such environments, biotopes are distributed along a gradient taking into account the mixing with marine waters and the content of pollutants or nutrients (SerandreiBarbero et al., 2003), as they are characterized by the presence and abundance of species with different levels of sensitivity or tolerance to environmental stress. In this regard, the assemblages making up different biotopes are closely linked to ecological groups, as defined by Grall and Glémarec (1997) and by Borja et al. (2000): species grouped according to their sensitivity to an environmental stress gradient, such as the organic matter content.

Preliminary results obtained by Alve et al. (2016) using soft-bottom benthic foraminifera in the definition of ecological groups for the North East Atlantic margin encouraged us to consider these organisms as being

\footnotetext{
* Corresponding author.

E-mail address: sandra.donnici@cnr.it (S. Donnici).
} 
able to play a key role in defining different environmental stress levels through the application of the Marine Biotic Index AMBI.

Recent efforts to extend the use of the AMBI index for Mediterranean soft bottom foraminifera (Jorissen et al., 2018) motivated us to test this method in the sediments of the Laizhou Bay (Bohai Sea, China) seeking to confirm benthic foraminifera as a standardized biomonitoring tool given their ability to trace the limits of the most polluted areas.

A quantity of scientific literature has described different aspects of foraminiferal fauna found in the seas of China. One of the first comprehensive delineation of benthic and planktonic foraminiferal assemblages from a large area off the coast of China was provided by Zheng (1990). Recent studies have delved into the environmental significance of morphological variations in specific taxa (Lei et al., 2017a) while other research aimed to understand the environmental implications of foraminifera and their application in paleoenvironment reconstruction ( $\mathrm{Li}$ et al., 2014; Lei et al., 2017b). Some researchers have tried to use benthic foraminifera as bio-monitors for trace metal pollution in marginal marine environments by investigating their relationships with heavy metals ( $\mathrm{Li}$ et al., 2015) or evaluated their responses to an oil spill through specific indexes (Lei et al., 2015). Foraminiferal species from the Bohai Sea and the Yellow Sea was reported by Lei and Li (2016) in the "Atlas of Benthic Foraminifera from China Seas". The distribution of benthic foraminiferal species revealing distinct foraminiferal assemblages in the Laizhou Bay was analyzed in detail by Li et al. (2010) and Wang et al. (2016).

Despite the rich scientific production, a new method can still be provided, using benthic foraminifera for the evaluation of the ecological quality status (EcoQS) of marine soft-bottom habitats. In the Yellow River Delta and the eastern part of the Laizhou Bay, the AMBI index for macrobenthos was calculated by Li et al. (2017). As pointed out by the authors, the assignment of the species to the ecological groups based on different tolerance and sensitivity to a stress gradient is crucial in calculating the value of AMBI.

The availability of a set of sediment samples whose heavy metals distribution and contamination assessment is known allows us a direct comparison with the distribution of foraminifera. The final aim of the work is the attempt to extend to the Laizhou Bay (Yellow River Delta system) the calculation of the ecological status of the ecosystem through the Foram-AMBI.

The main objectives of the present study could be summarized in the following points: 1) assigning the main benthic foraminifera species into one of the already defined ecological groups (Alve et al., 2016; Jorissen et al., 2018); 2) checking whether the assignment of the benthic foraminifera taxa obtained in the Mediterranean Sea is applicable to the same taxa recognized in the Laizhou Bay; 3) comparing the assessment of the ecological status of the soft bottom ecosystems obtained through the Foram-AMBI with that obtained through foraminiferal biotopes; 4) providing an assessment of the ecological status of the Laizhou Bay ecosystems.

\section{Study area}

The study area is part of the Laizhou Bay, which is located at the southern tip of the Bohai Sea between the Yellow River Delta and the Shandong Peninsula (Fig. 1). It covers an area of $\sim 7000 \mathrm{~km}^{2}$ and is characterized by a relatively flat seafloor morphology, typical of a semiclosed shallow basin influenced by a high accumulation of riverine sediments. Sedimentation rate in the shelf areas of the Bay, which is mostly from the Yellow River discharge, averages $1-2 \mathrm{~cm} \mathrm{a}^{-1}$ (Zhou et al., 2016), and the sea bottom gradually deepens from the tidal flats bounding the western sector up to 10-15 m northward. However, over the past few decades, significant changes in both estuarine sediment dynamics and the morphology of the Yellow River Delta system have been triggered by human activities in the river basin and climate change. Sediment discharge into the sea has decreased by $\sim 90 \%$ in the last six decades (Wang et al., 2010).

Qiao et al., 2010 analyzed the marine circulation of Laizhou Bay and found that the distribution and transport of suspended sediments is essentially dominated by tidal and residual currents. Sediments from the Yellow River move south and southeast and are distributed by sea currents with counterclockwise and clockwise circulation on both sides of the river mouth.

The watercourses have a great influence on the eco-environment of the Laizhou Bay through the freshwater and pollution inputs. The salinity in most sectors of the Bay is less than 30 ppt because of the freshwater discharge of the Yellow River, together with those of the Xiaoqing and Jiaolai Rivers, and a dozen of minor watercourses. The rapid development of urbanization and industrialization, aquaculture farms, and many other uses of the coastal area have made the pristine conditions of the Bay under great threat.

Numerous research based on monitoring has been carried out in recent years for the evaluation of the quality of the bottom sediments in the Bohai Sea and the Laizhou Bay. Analysis of total concentrations and
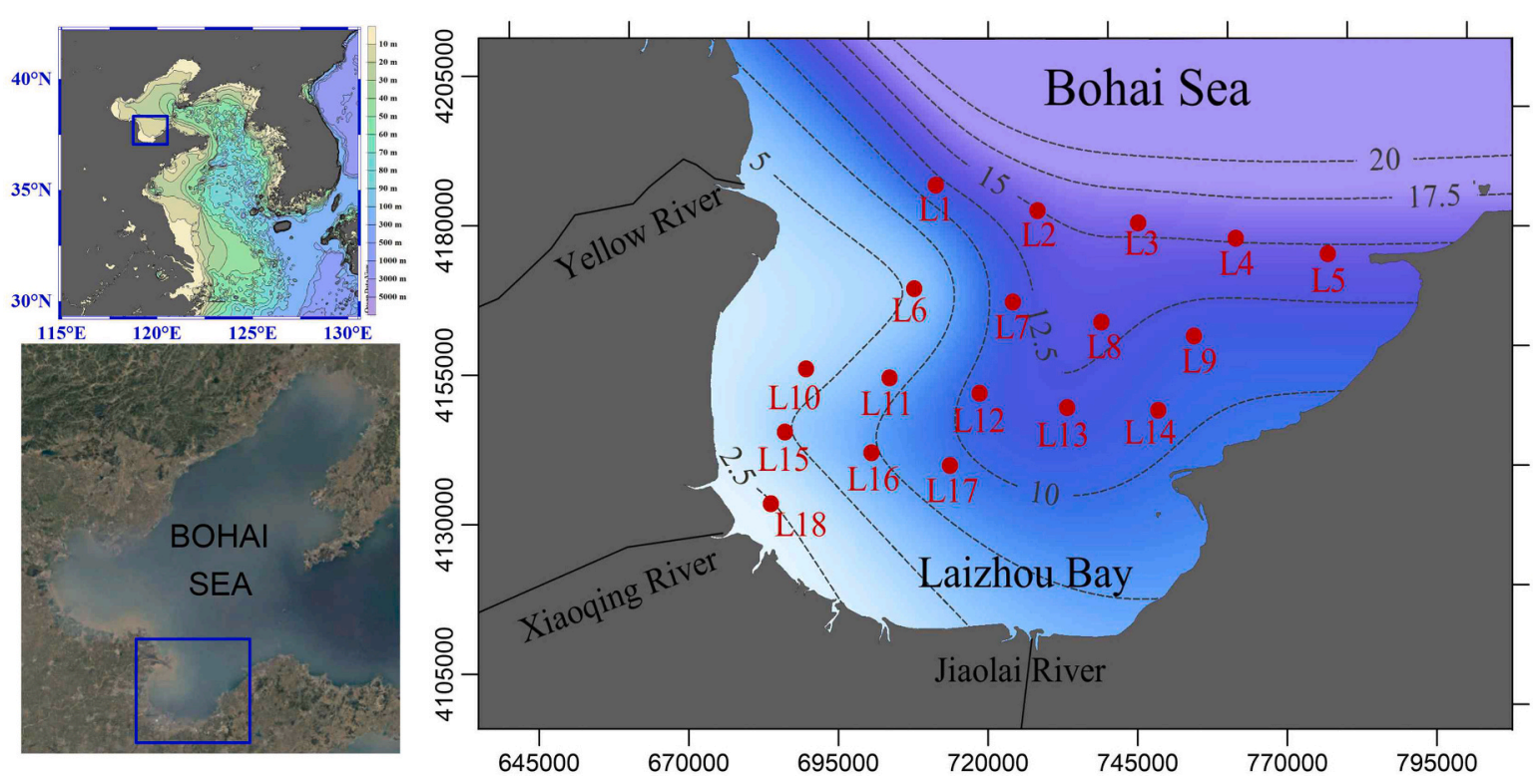

Fig. 1. Satellite image of the Bohai Sea (China) and location of the sampling stations in the Laizhou Bay with bathymetric map as background. 
Table 1

Depth, water content, grain size and total organic carbon (TOC) in the 18 analyzed samples of the Laizhou Bay.

\begin{tabular}{|c|c|c|c|c|c|c|c|c|}
\hline Sampling site & Longitude (E) & Latitude (N) & Depth (m) & Water content $(\%)$ & Clay (\%) & Silt fraction (\%) & Sand fraction (\%) & TOC (\%) \\
\hline L1 & $37^{\circ} 47^{\prime} 24.2^{\prime \prime}$ & $119^{\circ} 23^{\prime} 13.4^{\prime \prime}$ & 12.9 & 48.4 & 26.3 & 67.5 & 6.2 & 1.12 \\
\hline L2 & $37^{\circ} 45^{\prime} 10.7^{\prime \prime}$ & $119^{\circ} 34^{\prime} 57.0^{\prime \prime}$ & 14.8 & 43.9 & 24.2 & 70.6 & 5.2 & 1.51 \\
\hline L3 & $37^{\circ} 44^{\prime} 04.5^{\prime \prime}$ & $119^{\circ} 46^{\prime} 35.6^{\prime \prime}$ & 15.2 & 37.5 & 16.6 & 66.6 & 16.8 & 0.61 \\
\hline L4 & $37^{\circ} 42^{\prime} 42.5^{\prime \prime}$ & $119^{\circ} 57^{\prime} 54.5^{\prime \prime}$ & 15.4 & 30.4 & 13.6 & 72.9 & 13.5 & 0.43 \\
\hline L5 & $37^{\circ} 41^{\prime} 21.8^{\prime \prime}$ & $120^{\circ} 08^{\prime} 32.6^{\prime \prime}$ & 14.6 & 37.7 & 15.3 & 69.5 & 15.3 & 1.20 \\
\hline L6 & $37^{\circ} 38^{\prime} 23.7^{\prime \prime}$ & $119^{\circ} 20^{\prime} 41.0^{\prime \prime}$ & 4.2 & 36.1 & 17.8 & 63.0 & 19.2 & 0.84 \\
\hline L7 & $37^{\circ} 37^{\prime} 14.1^{\prime \prime}$ & $119^{\circ} 32^{\prime} 07.7^{\prime \prime}$ & 12.3 & 35.9 & 20.8 & 65.2 & 14.0 & 0.75 \\
\hline L8 & $37^{\circ} 35^{\prime} 31.5^{\prime \prime}$ & $119^{\circ} 42^{\prime} 20.1^{\prime \prime}$ & 13.2 & 26.1 & 4.0 & 48.8 & 47.2 & 0.24 \\
\hline L9 & $37^{\circ} 34^{\prime} 14.8^{\prime \prime}$ & $119^{\circ} 53^{\prime} 01.3^{\prime \prime}$ & 11.0 & 25.3 & 5.5 & 49.8 & 44.8 & 0.22 \\
\hline L10 & $37^{\circ} 31^{\prime} 26.6^{\prime \prime}$ & $119^{\circ} 08^{\prime} 16.0^{\prime \prime}$ & 3.6 & 28.1 & 10.1 & 66.1 & 23.8 & 0.29 \\
\hline L11 & $37^{\circ} 30^{\prime} 40.9^{\prime \prime}$ & $119^{\circ} 17^{\prime} 53.1^{\prime \prime}$ & 6.9 & 22.2 & 6.7 & 42.5 & 50.8 & 0.19 \\
\hline L12 & $37^{\circ} 29^{\prime} 20.2^{\prime \prime}$ & $119^{\circ} 28^{\prime} 14.9^{\prime \prime}$ & 11.3 & 30.1 & 25.0 & 69.7 & 5.3 & 1.40 \\
\hline L13 & $37^{\circ} 28^{\prime} 04.3^{\prime \prime}$ & $119^{\circ} 38^{\prime} 23.1^{\prime \prime}$ & 12.2 & 27.9 & 10.3 & 52.9 & 36.8 & 0.31 \\
\hline L14 & $37^{\circ} 27^{\prime} 49.3^{\prime \prime}$ & $119^{\circ} 48^{\prime} 55.5^{\prime \prime}$ & 10.6 & 27.5 & 5.0 & 49.5 & 45.5 & 0.15 \\
\hline L15 & $37^{\circ} 25^{\prime} 54.0^{\prime \prime}$ & $119^{\circ} 05^{\prime} 51.2^{\prime \prime}$ & 6.4 & 41.5 & 23.9 & 71.9 & 4.3 & 0.70 \\
\hline L16 & $37^{\circ} 24^{\prime} 10.9^{\prime \prime}$ & $119^{\circ} 15^{\prime} 48.7^{\prime \prime}$ & 7.7 & 37.5 & 23.7 & 72.2 & 4.1 & 0.89 \\
\hline L17 & $37^{\circ} 23^{\prime} 06.1^{\prime \prime}$ & $119^{\circ} 24^{\prime} 55.6^{\prime \prime}$ & 9.1 & 47.8 & 24.7 & 71.7 & 3.6 & 1.01 \\
\hline L18 & $37^{\circ} 19^{\prime} 46.0^{\prime \prime}$ & $119^{\circ} 04^{\prime} 15.1^{\prime \prime}$ & 2.0 & 24.4 & 3.9 & 36.9 & 59.3 & 0.16 \\
\hline
\end{tabular}

fractionation of heavy metals reveals that relatively higher concentrations of metals in the Laizhou Bay were mainly distributed near the new and old mouths of the Yellow River, the mouths of the Xiaoqing River, and in the middle of the Bay. The risk assessment indices revealed a pollution risk by $\mathrm{Cd}$, especially in sites near the river mouths and in the southwestern Laizhou Bay (e.g., Zhuang and Gao, 2014). Some of the research analyzed the content of heavy metals in the surface sediments from the intertidal zone of the Laizhou Bay and pointed out that the occurrence of $\mathrm{As}, \mathrm{Cr}, \mathrm{Cu}, \mathrm{Zn}, \mathrm{Ni}$, and $\mathrm{Pb}$ falls within the range of their natural variability while only $\mathrm{Cd}$ and $\mathrm{Hg}$ have an anthropogenic enrichment (Zhang and Gao, 2015). In general, the potential ecological risk due to the presence of heavy metals is overall low to moderate with only $21 \%$ of probability of being toxic for the biota (Zhuang and Gao, 2014).

Other studies, using marine biotic indices (e.g., Ni et al., 2019), assessed a slight disturbance of the ecological quality of macrobenthos habitats in the northern Laizhou Bay, despite the fact that the Bohai Sea is heavily affected by anthropogenic activities. Focusing on the Yellow River Delta, Li et al. (2017) have shown that the number and abundance of macrobenthos species increased towards the most external zone. Trace metals, water temperature, and depth are the main environmental variables affecting the distribution pattern of macrobenthic assemblages.

\section{Materials and methods}

In order to study foraminiferal fauna, 18 samples collected in October 2011 (Gao et al., 2013) from the surface sediments of the Laizhou Bay were analyzed (Table 1). Samples of about $50 \mathrm{~g}$ of dry weight were washed over a sieve of $63 \mu \mathrm{m}$ mesh to eliminate the muddy fraction. Sample fraction $>125 \mu \mathrm{m}$ was split to obtain at least 300 specimens in every sample. In samples containing less than 300 specimens, all specimens were determined and the classification followed the taxonomic order of Loeblich and Tappan (1987). For the identification of taxa, we referred to the Atlas of Lei and Li (2016) and to the last updates on the World Register of Marine Species (WoRMS; Hayward et al., 2020). The abundance of foraminifera expressed as Number of individuals per gram of bulk sediment (Nfor/g) was determined. We identified and counted foraminifera under the stereomicroscope. The examination of the fraction between $63 \mu \mathrm{m}$ and $125 \mu \mathrm{m}$ shows the presence of a very large number of juvenile individuals of doubtful identification, since in transitional environments foraminifera reach morphological maturity later than in the open sea (Albani et al., 2007).

Since any change in biotic or abiotic factors can modify living assemblages, the total foraminiferal assemblage (living + dead) has been analyzed. The total assemblage in a given area of the seabed integrates the faunal variations caused by changes in chemical and physical parameters; moreover, it also takes into account all the seasonal variations due to productivity peaks of different taxa during the year since their reproduction is asynchronous (Buzas et al., 2002; Serandrei-Barbero et al., 2003).

PAST software (Hammer et al., 2001) was used for the calculation of the Shannon diversity index $\mathrm{H}$ and the multivariate statistical analysis of the foraminifera dataset. The Shannon index $\mathrm{H}$ takes into account the number of individuals as well as number of taxa. It varies from 0 for communities with only a single taxon to high values for communities with many taxa, each with few individuals.

We calculated the Pearson correlation coefficient $r$, which varies between +1 and -1 and yields a measure of the strength of the linear relation between two variables, to compare foraminifera percentages with grain size of sediment samples. In our dataset, $r$ is significant for values $>|0.532|$ with a 95\% confidence interval. Detrended Correspondence Analysis (DCA) was applied to the data set of 14 non-sterile sediment samples and 34 foraminiferal species. The species represented by a single individual were not taken into account in the multivariate statistical analysis. The K-means cluster analysis was used to identify clusters of samples based on the results of DCA (first three linear transformations).

We compared the relative abundance of foraminiferal species and total organic carbon (TOC) content of surface sediments to assign main foraminiferal species to one of five ecological groups described by Alve et al. (2016) and Jorissen et al. (2018). The group I includes species sensitive to organic enrichment, existent in natural, unpolluted ecosystems. The group II consists of species insensitive to the first stages of organic enrichment, which disappear with increasing organic supplies. Groups III, IV, and V are composed of opportunist taxa belonging to three different levels.

Then, the sensitivity index based on benthic foraminiferal faunas was obtained following Alve et al. (2016), who first defined the ForamAMBI. Foram-AMBI was computed using the formula given by Borja et al. (2000), which is based on the sum of the relative abundances of all species in different ecological groups: 
where G1-G5 are the determined ecological groups.

In Borja et al. (2003), the AMBI index values is comprised between 0 and 7, providing 5 levels of pollution classification, with the lowest values indicating unpolluted sites and high ecological status, and the highest ones indicating heavily polluted sites and bad ecological status. The index has been validated and applied to different impact sources and geographical areas (Borja et al., 2000, 2003), demonstrating its usefulness.

\section{Results}

\subsection{The foraminiferal species}

Of the 18 sediment samples examined, 4 were devoid of foraminifera, and the remaining 14 contained between 4 and 2221 foraminifers per gram of sediment (Nfor/g). The samples collected from the northeastern part of the study area (L1, L6, L10, and L11) did not contain foraminifera, while the samples collected from the south-western part (L9, L13, and L14) had the highest content of foraminifera (Fig. 2).

Among 50 detected foraminiferal species, 20 have been found in at least 5 samples (Table 2). The number of species per sample ranges from 10 to 26 , in sample L15 and L4 respectively, and the overall average is 18.

Porosononion granosum is the most abundant species with an average abundance of $21 \%$, Ammonia beccarii 14\%, Cribroelphidium magellanicum 13\%, Elphidium advenum $12 \%$ and Quinqueloculina akneriana $10 \%$ (Table 2).

In Fig. 3, the spatial distribution of the percentages of sand, silt, clay, and TOC is shown. Fine sediments predominate in samples from the north and west of the bay, while sand is more abundant in the centraleastern samples, which have the lowest TOC content.

Only two species show significant correlation with grain size: Quinqueloculina seminula correlates positively with clay $(r=0.68)$ and silt $(r$ $=0.59)$ and negatively with sand $(r=0.65)$, while Quinqueloculina subungeriana correlates positively with sand $(r=0.59)$ and negatively with silt $(r=0.62)$.

\subsection{The foraminiferal biotopes}

Detrended Correspondence Analysis on the counted species in each sample allowed the identification of groups of similar samples represented by neighboring dots (Fig. 4). The first two transformations of DCA explain $37 \%$ of the total variability. The cluster analysis identified five clusters of samples corresponding to five foraminiferal biotopes. Despite the apparent proximity of cluster 1 to cluster 2 in Fig. 4, however the two clusters are actually separate on the Axis1-Axis3 plane, not represented in the figure.

Biotope 1) sample L18: A. beccarii is the dominant species (31\%), C. magellanicum (19\%) and P. granosum (19\%) are co-dominant.

Biotope 2) samples L12, L15 and L16: Q. akneriana is the dominant species (29\%) and A. beccarii (13-23\%) co-dominant; Quinqueloculina seminula (6-9\%) and $P$. granosum (3-14\%) are relevant species.

Biotope 3) samples L7 and L17: P. granosum (22-23\%) is the dominant species; A. beccarii (13-18\%) is co-dominant, and E. advenum (9-23\%) and Q. seminula (7-12\%) are relevant species.

Biotope 4) samples L2 and L3: $P$. granosum (15-20\%) and C. magellanicum (15-30\%) are co-dominant species, A. beccarii (11-14\%) and Q. seminula (6-9\%) relevant species.

Biotope 5) samples L4, L5, L8, L9, L13, and L14: $P$. granosum (14-34\%) and C. magellanicum (6-32\%) are co-dominant species and E. advenum (14\%) is relevant, A. beccarii (5-13\%) and $Q$. seminula (1-6\%) have less abundance than the other biotopes, while the content of Buccella frigida granulata and Triloculina trigonula is higher than other biotopes.

From Biotope 1) to 5) we observed a decrease in the relative abundance of $A$. beccarii and $Q$. akneriana and an increase in other species such as $P$. granosum, $C$. magellanicum and $B$. frigida granulata.

\subsection{The ecological groups}

The relative abundance of the most abundant/significant foraminiferal species was therefore compared with the sedimentary TOC concentration in each sample (Fig. 5). These species have been assigned to

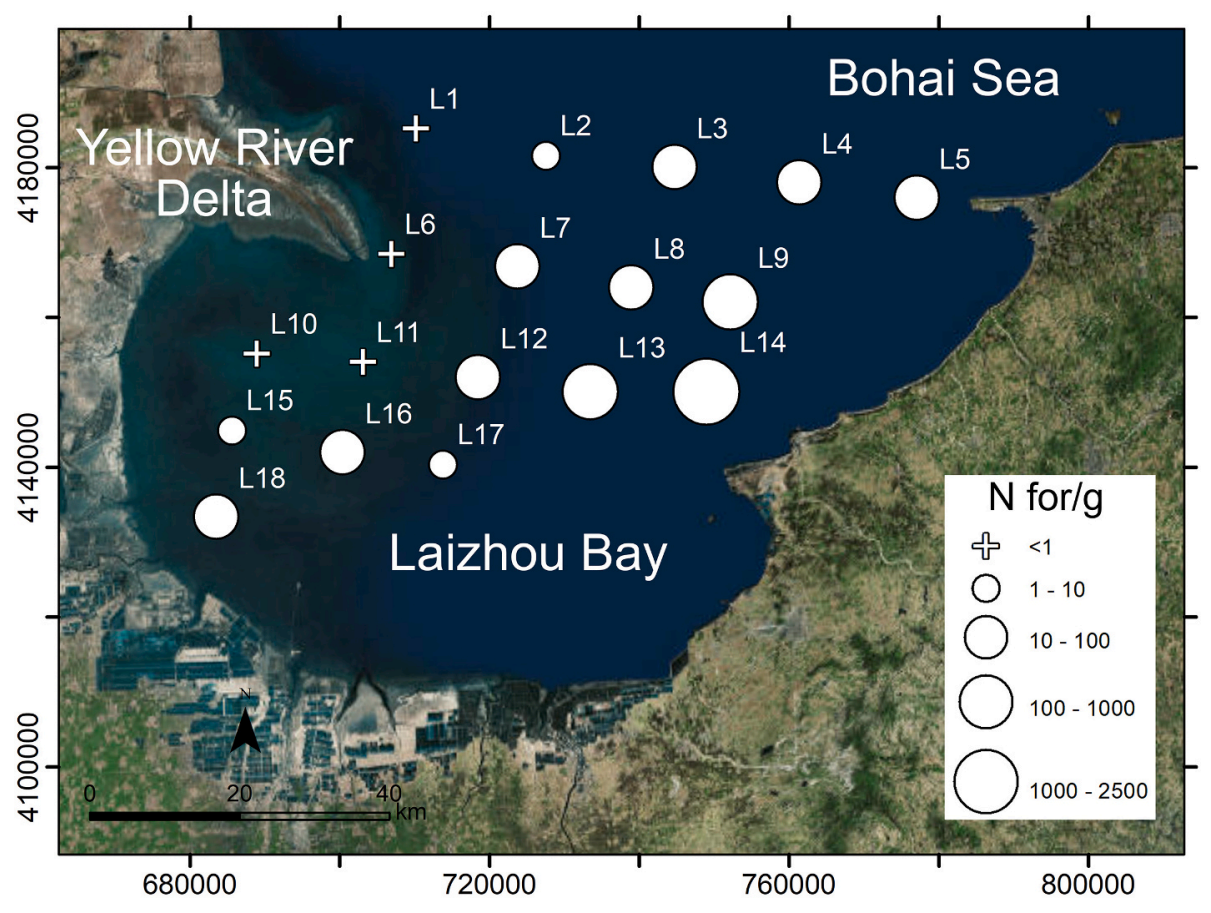

Fig. 2. Distribution map of number of foraminifera per gram of sediment (Nfor/g) in the studied sampling sites. 
Table 2

Relative abundance (\%) of the major species of benthic foraminifera.

\begin{tabular}{|c|c|c|c|c|c|c|c|c|c|c|c|c|c|c|c|c|c|c|}
\hline & L2 & L3 & L4 & L5 & L7 & L8 & L9 & L12 & L13 & L14 & L15 & L16 & L17 & L18 & $\mathrm{N}$ & mean & $\min$ & $\max$ \\
\hline $\begin{array}{l}\text { Cribrostomoides australensis } \\
\quad \text { (Albani, 1978) }\end{array}$ & 0.3 & 1.0 & 0.6 & 1.2 & & 0.8 & & & & & & & & & 5 & 0.8 & 0.3 & 1.2 \\
\hline $\begin{array}{l}\text { Ammobaculites agglutinans } \\
\text { (d'Orbigny, 1846) }\end{array}$ & 7.2 & 7.3 & 5.5 & 2.8 & 2.1 & 0.8 & 1.5 & 0.8 & 1.9 & & 15.3 & 1.9 & 1.9 & & 12 & 4.1 & 0.8 & 15.3 \\
\hline $\begin{array}{l}\text { Spiroloculina communis } \\
\text { Cushman \& Todd, } 1944\end{array}$ & & & 0.6 & 0.4 & 0.3 & 0.4 & & & & 1.1 & & & & & 5 & 0.6 & 0.3 & 1.1 \\
\hline $\begin{array}{l}\text { Quinqueloculina akneriana } \\
\text { d'Orbigny, } 1846\end{array}$ & 1.0 & 2.4 & 3.2 & 0.4 & 6.3 & 2.0 & 0.8 & 29.0 & 3.6 & 3.4 & 37.6 & 29.4 & 11.3 & 16.2 & 14 & 10.5 & 0.4 & 37.6 \\
\hline $\begin{array}{l}\text { Quinqueloculina argunica } \\
\text { (Gerke, 1938) }\end{array}$ & 2.3 & 0.7 & 1.6 & 1.2 & 1.6 & & 1.9 & 5.0 & 4.5 & 1.1 & 0.5 & 1.3 & 1.7 & 1.7 & 13 & 1.9 & 0.5 & 5.0 \\
\hline $\begin{array}{l}\text { Quinqueloculina seminula } \\
\text { (Linné, 1758) }\end{array}$ & 9.1 & 5.9 & 5.8 & 1.6 & 6.8 & 0.4 & 2.1 & 3.7 & 2.3 & 1.1 & 7.9 & 22.2 & 12.1 & 2.5 & 14 & 6.0 & 0.4 & 22.2 \\
\hline $\begin{array}{l}\text { Quinqueloculina subungeriana } \\
\text { Serova, } 1960\end{array}$ & & & & 0.4 & 0.3 & 0.4 & 0.8 & 0.4 & & & & & & 0.8 & 6 & 0.5 & 0.3 & 0.8 \\
\hline $\begin{array}{l}\text { Triloculina trigonula } \\
\text { (Lamarck, 1804) }\end{array}$ & 0.3 & & 1.0 & & 0.8 & 2.0 & 0.2 & 1.7 & 3.9 & 10.2 & & 0.6 & 3.0 & 0.3 & 11 & 2.2 & 0.2 & 10.2 \\
\hline $\begin{array}{l}\text { Buccella frigida granulata (di } \\
\text { Napoli Alliata, 1952) }\end{array}$ & & 1.0 & 3.2 & 8.1 & 1.1 & 3.2 & 4.4 & 0.8 & 1.6 & 1.5 & & & 1.1 & 1.7 & 11 & 2.5 & 0.8 & 8.1 \\
\hline $\begin{array}{l}\text { Ammonia beccarii (Linnè, } \\
\text { 1758) }\end{array}$ & 14.3 & 11.5 & 4.9 & 8.1 & 13.2 & 11.3 & 12.6 & 17.0 & 10.4 & 7.0 & 12.7 & 22.8 & 17.6 & 30.8 & 14 & 13.9 & 4.9 & 30.8 \\
\hline $\begin{array}{l}\text { Ammonia pauciloculata } \\
\quad \text { (Phleger \& Parker, 1951) }\end{array}$ & & 0.3 & 0.6 & & & & & & & & & 0.3 & 0.6 & 1.1 & 5 & 0.6 & 0.3 & 1.1 \\
\hline $\begin{array}{l}\text { Cribroelphidium excavatum } \\
\text { (Terquem, 1875) }\end{array}$ & & & 1.6 & & 1.1 & & 8.6 & 1.7 & & 1.9 & & & & & 5 & 3.0 & 1.1 & 8.6 \\
\hline $\begin{array}{l}\text { Cribroelphidium incertum } \\
\text { (Williamson, 1858) }\end{array}$ & & 8.7 & 1.3 & 1.2 & 1.1 & & & & & & & & 3.0 & & 5 & 3.1 & 1.1 & 8.7 \\
\hline $\begin{array}{l}\text { Cribroelphidium } \\
\text { magellanicum (Heron- } \\
\text { Allen \& Earland, 1932) }\end{array}$ & 15.3 & 28.9 & 19.5 & 15.4 & 8.7 & 28.3 & 5.9 & 2.5 & 9.1 & 31.8 & & 0.9 & 2.8 & 1.1 & 13 & 13.1 & 0.9 & 31.8 \\
\hline $\begin{array}{l}\text { Cribrononion translucens } \\
\text { (Natland, 1938) }\end{array}$ & 4.6 & 4.2 & 1.3 & 0.8 & 1.6 & 1.2 & 2.3 & 1.2 & 0.3 & 1.1 & 3.2 & 1.6 & 1.1 & 0.3 & 14 & 1.8 & 0.3 & 4.6 \\
\hline $\begin{array}{l}\text { Elphidium advenum } \\
\text { (Cushman, 1922) }\end{array}$ & 11.4 & 4.2 & 12.7 & 17.5 & 23.4 & 10.1 & 20.5 & 14.5 & 18.1 & 3.4 & & 0.3 & 9.1 & 14.0 & 13 & 12.3 & 0.3 & 23.4 \\
\hline $\begin{array}{l}\text { Elphidium crispum (Linnaeus, } \\
\text { 1758) }\end{array}$ & 0.3 & & 0.6 & & & 0.8 & 1.5 & & & 0.2 & & & & & 5 & 0.7 & 0.2 & 1.5 \\
\hline $\begin{array}{l}\text { Elphidium limbatum } \\
\text { (Chapman, 1907) }\end{array}$ & & & 2.9 & 1.6 & 0.8 & 1.6 & 0.4 & & 1.3 & 0.4 & & & & & 7 & 1.3 & 0.4 & 2.9 \\
\hline $\begin{array}{l}\text { Elphidium subincertum Asano, } \\
\quad 1950\end{array}$ & 9.4 & 2.8 & 7.8 & 5.3 & 7.1 & 10.1 & 5.0 & 4.1 & 7.1 & 20.1 & 16.9 & 1.6 & 11.6 & 1.4 & 14 & 7.9 & 1.4 & 20.1 \\
\hline $\begin{array}{l}\text { Porosononion granosum } \\
\text { (d'Orbigny, 1846) }\end{array}$ & 20.5 & 15.0 & 21.1 & 31.3 & 22.9 & 25.1 & 31.4 & 14.1 & 33.7 & 14.0 & 3.2 & 14.6 & 22.0 & 18.8 & 14 & 20.5 & 3.2 & 33.7 \\
\hline Other species & 3.9 & 5.9 & 3.9 & 2.4 & 1.1 & 1.2 & 0.0 & 3.3 & 2.3 & 1.9 & 2.6 & 2.5 & 1.1 & 9.2 & 14 & 3.0 & 0.0 & 9.2 \\
\hline $\mathrm{N}$ species & 19 & 23 & 26 & 19 & 21 & 17 & 16 & 17 & 17 & 18 & 10 & 15 & 17 & 20 & & 18 & 10 & 26 \\
\hline
\end{tabular}

the described ecological groups (Table 3). In some cases, we placed particular emphasis on the abundance of foraminifera in sandy substrates with TOC $<0.4 \%$, as mentioned by Jorissen et al. (2018).

Six species were assigned to the ecological group I, sensitive. Among them, T. trigonula and E. crispum were assigned into this group by observing the samples with high sandy percentage and TOC $<0.4 \%$, in the first part of the graph (Fig. 5a, b).

A. beccarii and C. magellanicum did not show a clear trend (even with low TOC values) (Fig. 5c, d) and could be classified into the ecological group II, indifferent, with other six species.

Five species were in the ecological group III, third-order opportunists. Among them, Ammobaculites agglutinans and Q. seminula were presented in Fig. 5e and f. P. granosum, which at first glance seems to belong to the ecological group II, indifferent, shows instead a very clear trend for TOC $<0.4 \%$ and we classified it into the ecological group III (Fig. 5g).

Cribroelphidium incertum is the only species grouped into the ecological group IV, second-order opportunists (Fig. 5h).

Classifying the species to the different ecological groups (Table 3), the marine biotic index AMBI was calculated for the 14 samples containing foraminifera for the assessment of ecological quality status (Table 4). In the Laizhou Bay, Foram-AMBI varied between 1.5 and 2.5, indicating unbalanced Benthic Community Health, Slightly Polluted Sites, and a good ecological quality status (Borja et al., 2003).

The AMBI index has a positive correlation with the associated sedimentary TOC and negative correlation with Shannon's biotic H index (Fig. 6a, b), although the correlation is not very strong (possibly due to an active hydrodynamics leading to physical disturbance of the sea bed). The AMBI/TOC correlation seems to work better for the more sandy samples, with TOC $<0.4 \%$, than for samples with TOC values $>$ $1 \%$.

\section{Discussion}

Foraminifera are not primary producers but consumers of primary production, thus they use dissolved organic matter and nutrients already synthesized by phytoplankton and bacteria. The type and availability of metabolized food particles in the environment controls their microhabitat (Jorissen et al., 1995) and the food supply directly controls their abundance (Schmiedl et al., 1997; Smart and Gooday, 1997). Given the occurrence of irregular and unpredictable productivity peaks, quantitative data can be significantly distorted whether only biocoenosis is considered. Productivity peaks are unpredictable, for they are triggered by the occasional supply of food (for example microalgal blooms) and they are irregular as well as strictly dependent on biotic interactions. Their dependence on food availability triggers mechanisms of mutual dependence (Donnici et al., 1997; Serandrei-Barbero et al., 2003). For example, Ammonia beccarii, a dominant species in temperate lagoons, shows productivity peaks in summer and low productivity in winter. Along the coast of the Adriatic Sea instead, the dominant species 

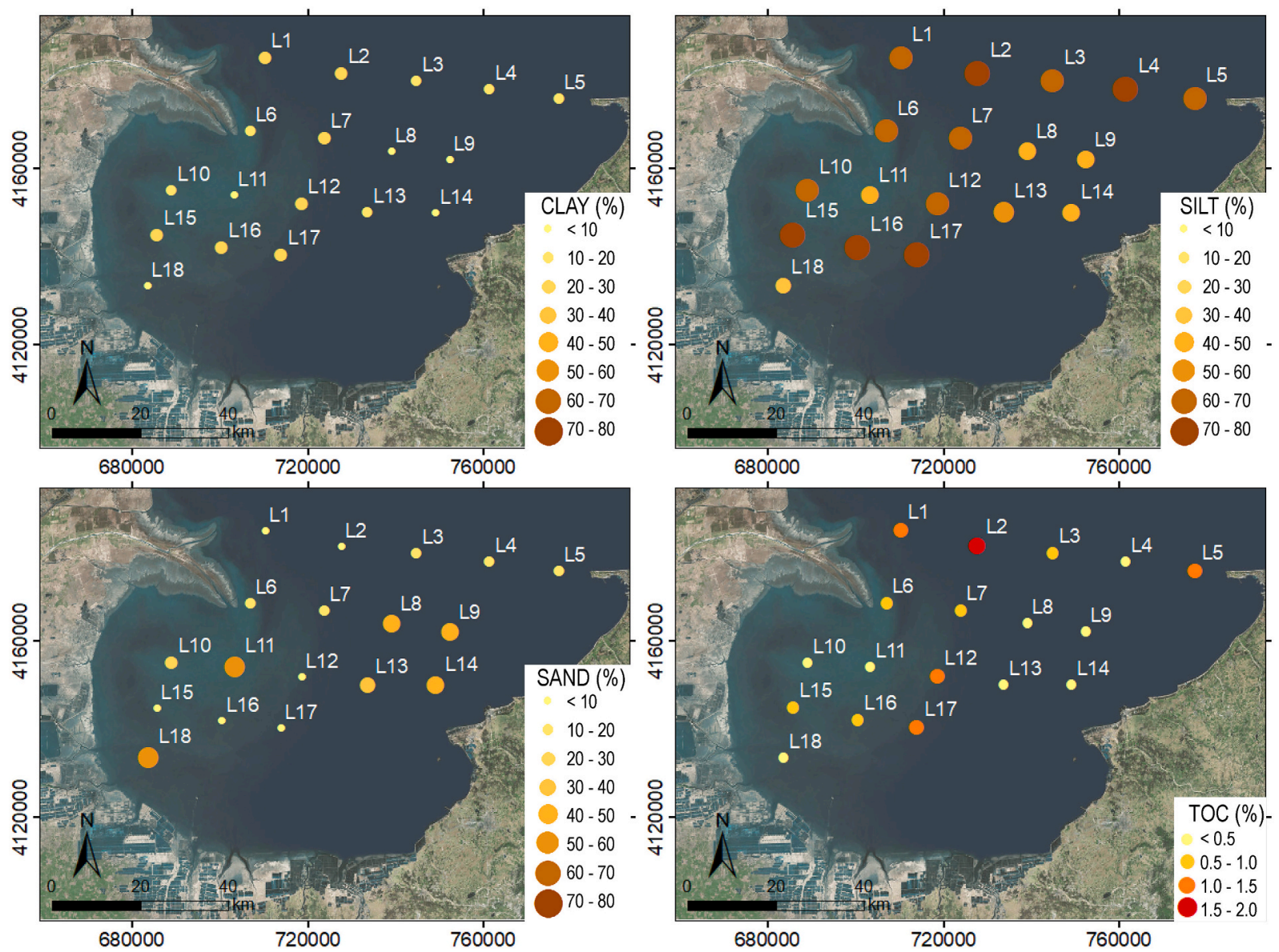

Fig. 3. Spatial distribution of the percentages of sand, silt, clay, and TOC in the sampled sediments.

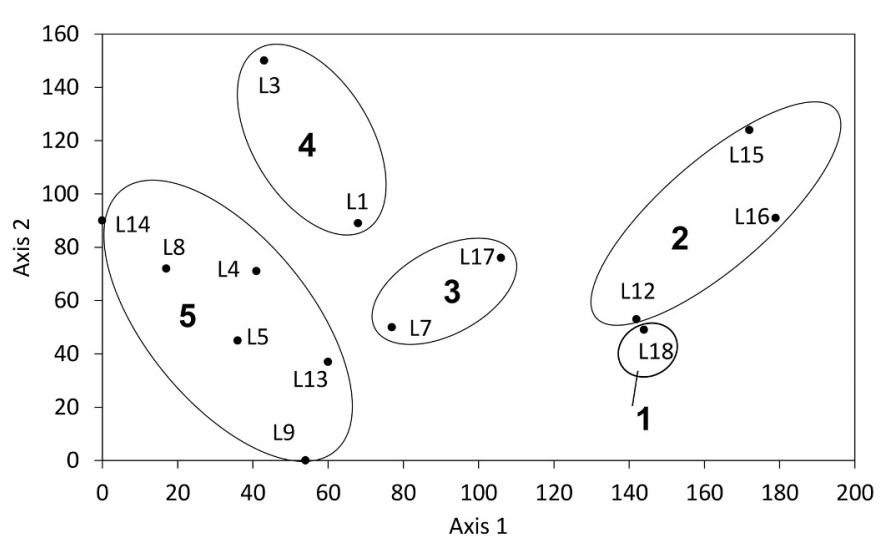

Fig. 4. Detrended Correspondence Analysis (DCA): the first two transformations explain $37 \%$ of total variability. The cluster analysis identified 5 clusters of samples. The projection on the Axis1-Axis2 plane of the DCA masks the effective distance between cluster 1 and cluster 2, which would be highlighted on the Axis1-Axis3 plane.

Planorbulina mediterranensis shows the highest productivity peaks in summer and A. beccarii is more abundant in winter. Within these mechanisms, only the total foraminiferal assemblage, given together by dead and living individuals is effectively indicative of the average quality of the environment (Albani et al., 1998; Serandrei-Barbero et al., 1999; Donnici and Serandrei-Barbero, 2002; Albani et al., 2007; Donnici et al., 2012). It represents the long term stability achieved, according to Buzas et al. (2002) through considerable short-term variability in space and time.

The detrended correspondence analysis based on the benthic foraminiferal total assemblage traces the foraminiferal biotopes extent in the Laizhou Bay (Fig. 7). The first group of samples (L1, L6, L10, and L11), closest to the Yellow River Delta, is devoid of Foraminifera. Accordingly, we can define this group as Biotope 0. Biotope 1, defined through a single sample (L18), is characterized by the highest abundance of A. beccarii, a species belonging to the ecological group II, able to tolerate highly different environmental conditions (Donnici and SerandreiBarbero, 2002). Despite being a sample close enough to the delta, the value of its ecological quality index is among the best compared with the examined samples, due to the reduced content of TOC. Biotope 2 covers the first sediment belt closest to the Yellow River Delta containing small quantities of foraminifera. The assemblage is dominated by Q. akneriana and $A$. beccarii. Although the ecological quality status remains within a "good" rate, this biotope has the lowest Shannon's diversity index $\mathrm{H}$ values and high Foram-AMBI index values, among the worst of the examined samples. Biotope 3 takes up an area adjacent to Biotope 2, but farther from the mouth of the Yellow River. The most abundant species of this assemblage is $P$. granosum, a third-order opportunist species, followed by $A$. beccarii and another opportunistic species, Q. seminula. These samples also provide a relatively high AMBI index, slightly lower than Biotope 2. Biotope 4 lies in the north-central part of the Laizhou Bay, open towards the Bohai Sea. P. granosum, C. magellanicum, $A$. beccarii, and $Q$. seminula, species belonging to the opportunists and indifferent ecological groups, dominate the foraminiferal assemblage, characterized by a specific diversity higher than the other biotopes. Finally, Biotope 5 occupies the eastern part of the Laizhou Bay. The main species are the same as for Biotope 4, but there is a significant content of species in the ecological group I - sensitive, such as T. trigonula and 

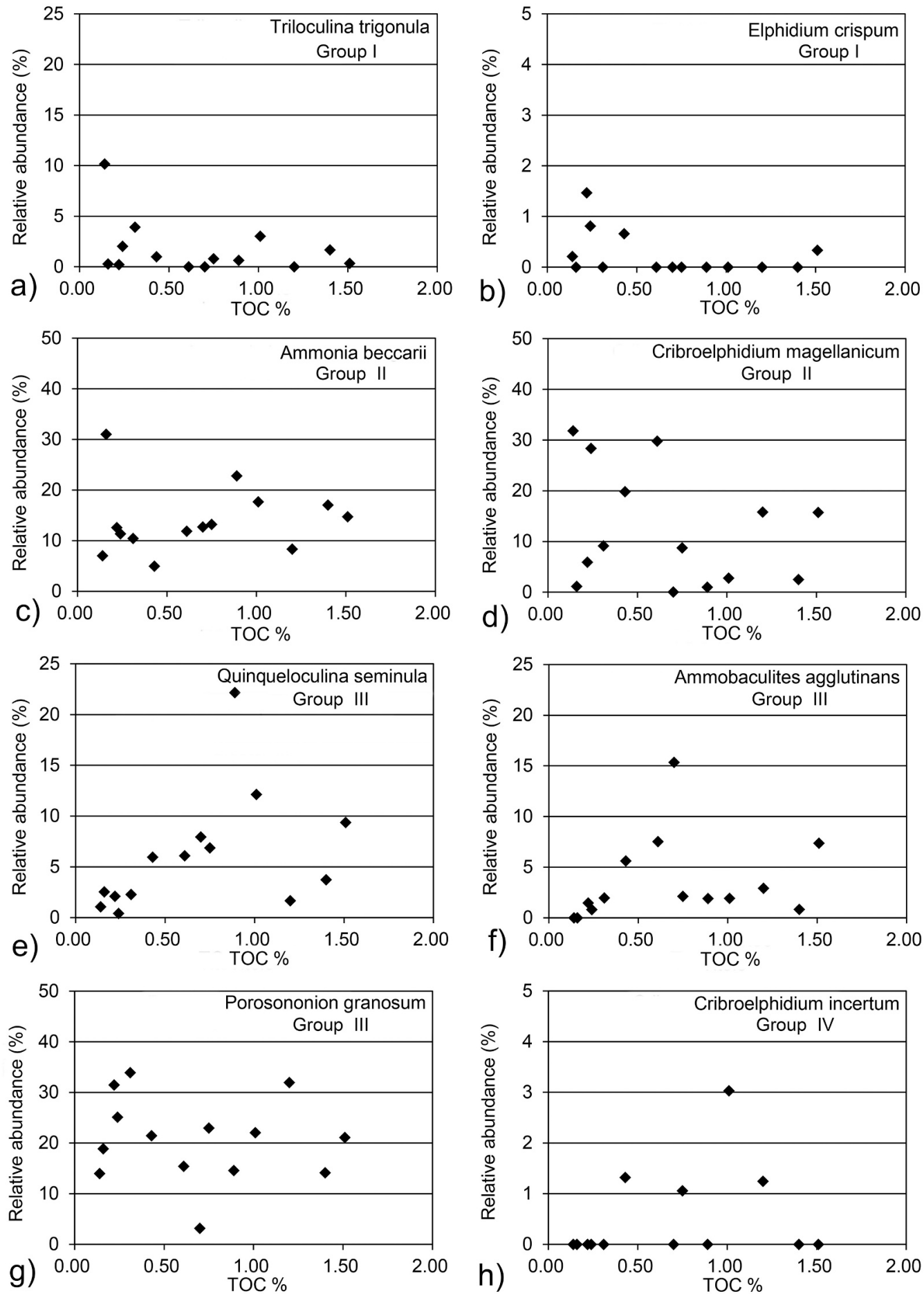

Fig. 5. Relative abundance of foraminiferal species vs. total organic carbon (TOC). Examples of species assignment to the ecological groups.

B. frigida granulata. For this reason, this biotope reaches the lowest values of Foram-AMBI, expressing the best ecological quality status (Fig. 7).

The foraminiferal biotopes trace a distribution pattern highlighting the ecological stress put together by pollution and the mixing of marine and fluvial waters. They show a progressive increase in the abundance and species diversity from the mouth of the Yellow River towards the sea and a zoning of the assemblages with a dominance of $A$. beccarii/Quinqueloculina spp. in the western part and Elphidiidae family in the eastern part correspondent with the results of Li et al. (2010). Moreover, the distribution of biotopes overlaps in the four zones (A, B, C, and D) based on the total relative abundances of benthic foraminiferal species (live plus dead) in 80 stations of the Laizhou Bay (Wang et al., 2016). Although our samples are fewer and occupy a wider area to the north and west, there is a significant correspondence both in the identified areas and in the composition of the assemblages. In Zone C, corresponding to our Biotope 0 , the Authors identified the cause of the sparse amount of foraminiferal tests in the dilution effect of high sedimentation rate along the southern Yellow River mouth. While in Zone A, corresponding to Biotope 5, near the outer bay and connected with the shallow area of the Bohai Sea, the assemblage is dominated by species of the Elphidiidae family and is mainly controlled by the deeper water 
Table 3

List of species of benthic foraminifera assigned to ecological groups.

\begin{tabular}{lll}
\hline Species & Ecological group \\
\hline Cribrostomoides australensis (Albani, 1978) & 2 & Indifferent \\
Ammobaculites agglutinans (d'Orbigny, 1846) & 3 & Opportunist \\
Spiroloculina communis Cushman \& Todd, 1944 & 1 & Sensitive \\
Quinqueloculina akneriana d'Orbigny, 1846 & 3 & Opportunist \\
Quinqueloculina argunica (Gerke, 1938) & 2 & Indifferent \\
Quinqueloculina seminula (Linné, 1758) & 3 & Opportunist \\
Quinqueloculina subungeriana Serova, 1960 & 1 & Sensitive \\
Triloculina trigonula (Lamarck, 1804) & 1 & Sensitive \\
Buccella frigida granulata (di Napoli Alliata, 1952) & 1 & Sensitive \\
Ammonia beccarii (Linnè, 1758) & 2 & Indifferent \\
Ammonia pauciloculata (Phleger \& Parker, 1951) & 2 & Indifferent \\
Cribroelphidium excavatum (Terquem, 1875) & 1 & Sensitive \\
Cribroelphidium incertum (Williamson, 1858) & 4 & Opportunist \\
Cribroelphidium magellanicum (Heron-Allen \& Earland, 1932) & 2 & Indifferent \\
Cribrononion translucens (Natland, 1938) & 2 & Indifferent \\
Elphidium advenum (Cushman, 1922) & 2 & Indifferent \\
Elphidium crispum (Linnaeus, 1758) & 1 & Sensitive \\
Elphidium limbatum (Chapman, 1907) ex depressulum Cushman, & 3 & Opportunist \\
1933 & & \\
Elphidium subincertum Asano, 1950 & 2 & Indifferent \\
Porosononion granosum (d'Orbigny, 1846) & 3 & Opportunist \\
\hline
\end{tabular}

depth, a higher bottom water salinity, and coarse sandy silt content.

The comparison of the ecological health status retrieved by the AMBI method through the macrobenthic assemblages (Li et al., 2017) with our results on benthic foraminifera highlights some consistency between the two methods. Specifically, the number and the abundance of macrobenthos species are significantly higher in the outermost zone of the Yellow River delta where we assessed the good ecological status. On the contrary, they are lower in the area close to the delta front where our samples are devoid of foraminifera.

Generally, organic enrichment can be associated with the presence of toxic chemical compounds in polluted sites. Given that there is often a positive correlation between TOC and chemical pollutants, in environments that have an anthropogenic influence foraminifera faunas can show a response to a sum of stress factors, given not only by organic enrichment but also by the simultaneous presence of chemical pollutants (Jorissen et al., 2018). In our study, the overall good assessment of the ecological quality status of the soft bottom habitats obtained through the Foram-AMBI is in accordance with the assessment of sediment quality performed on the same sediment samples of the study by Gao et al. (2013). The Authors calculated the ratio between the sulphide-bound metals extracted during cold acid extraction of sulphide and the total amount of sulphide volatilized, i.e. [SEM]/[AVS] ratio. This ratio is used as an indicator of the degree of pollution of sediments and suggests that the surface sediments of the Laizhou Bay were of high quality and not likely to cause negative effects on the ecosystem. The heavy metals were mainly from terrestrial sources, and especially $\mathrm{Cd}, \mathrm{Cr}$, and $\mathrm{Ni}$ had obvious anthropogenic sources (Zhuang and Gao, 2014). Another study by Zhang and Gao (2015) regarding the content of heavy metals in the surface sediments of the Laizhou Bay shows that their content falls within the range of their natural variability, while only $\mathrm{Cd}$ and $\mathrm{Hg}$ indicate an anthropogenic enrichment. In the study area, the potential ecological risk due to the presence of heavy metals is overall low to moderate, and higher for $\mathrm{Hg}$. Overall, the analyzed pollutants presented a low risk for the environment with only $21 \%$ of probability of being toxic for the biota. The granulometry of the sediments and the percentage of TOC generally control the metal contents and could impact on some foraminiferal species. It is important to know the relationships between granulometry of the substrate and the distribution of foraminifera species to understand whether abrupt faunal changes are related to changes in grain size. Also, the distribution of a species along the TOC gradient can be more correctly assessed if the grain size of the sediment is taken into account. In the present study, the Pearson correlation $r$ indicates that only two species have a significant correlation with grain size. The opportunist $Q$. seminula shows negative values of correlation $r$ with sand and positive with the fine sediment fractions. Conversely, the sensitive $Q$. subungeriana correlates positively with sand and, even though negligible, negatively with clay. The other sensitive species show no significant correlation with grain size of sediments. Negative $r$ is generally shown with clay, but the values are not significant.

The Foram-AMBI index, which provides the ecological quality status of the marine environment in the sediment samples, follows an evident trend, with a lower and, therefore, better value in the areas where the influence of the Yellow River is smaller (Fig. 7). The main factors controlling the distribution of benthic foraminifera species in the Laizhou Bay are therefore the distance from the mouth of the Yellow River and the TOC in the sediments. In particular, the western and southern Laizhou Bay is where most of the transport and deposition into the sea of the finer-grained suspended sediment of the Yellow River is confined (Zhan et al., 2020). Sensitive species, belonging to the ecological group I, are more abundant in Biotope 5, where they represent 6 to $15 \%$ of the foraminiferal assemblage. This Biotope occupy the eastern part of
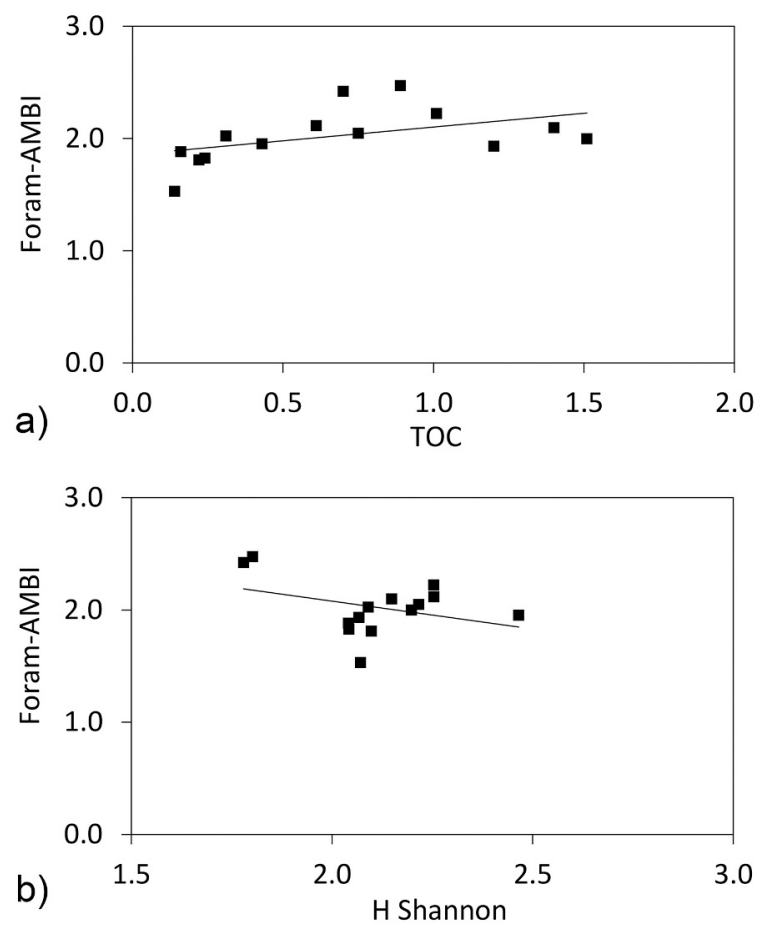

Fig. 6. Correlation of Foram-AMBI vs. Shannon's diversity index $\mathrm{H}$ (a) and Foram-AMBI vs. TOC (b).

Table 4

Marine Biotic Index based on Foraminifera (Foram-AMBI), Shannon's diversity index (H) and total organic carbon (TOC) content of surface sediments in the Laizhou Bay.

\begin{tabular}{|c|c|c|c|c|c|c|c|c|c|c|c|c|c|c|}
\hline & L2 & L3 & L4 & L5 & L7 & L8 & L9 & L12 & L13 & L14 & L15 & L16 & L17 & L18 \\
\hline Foram-AMBI & 2.00 & 2.12 & 1.95 & 1.93 & 2.05 & 1.83 & 1.81 & 2.10 & 2.02 & 1.53 & 2.42 & 2.47 & 2.22 & 1.88 \\
\hline H Shannon & 2.20 & 2.25 & 2.47 & 2.07 & 2.22 & 2.04 & 2.10 & 2.15 & 2.09 & 2.07 & 1.78 & 1.80 & 2.25 & 2.04 \\
\hline TOC & 1.51 & 0.61 & 0.43 & 1.20 & 0.75 & 0.24 & 0.22 & 1.40 & 0.31 & 0.14 & 0.70 & 0.89 & 1.01 & 0.16 \\
\hline
\end{tabular}




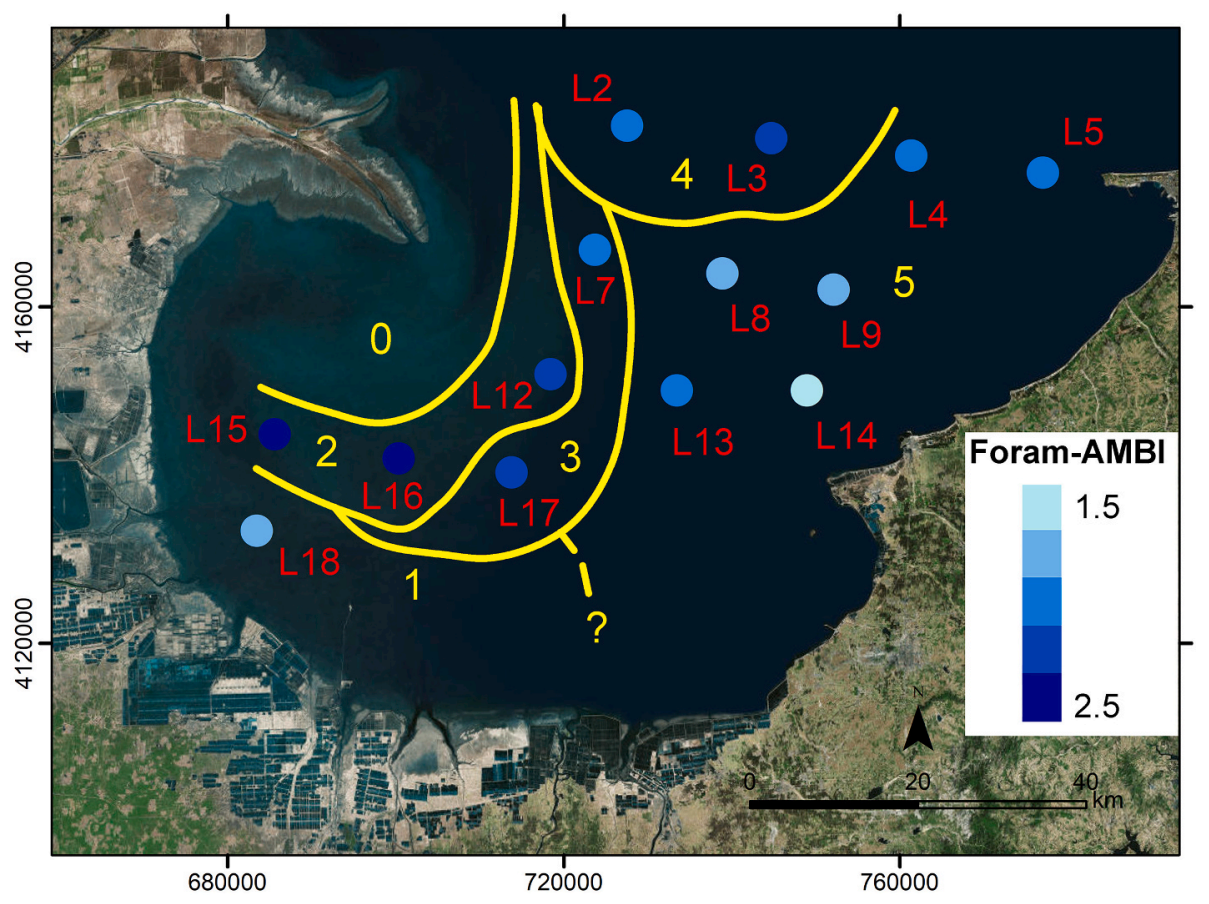

Fig. 7. Distribution of benthic foraminiferal biotopes (0-5) and Foram-AMBI in the study area.

Laizhou Bay, the furthest from the mouth of the Yellow River, where sea currents (with counterclockwise and clockwise circulation) ensure good exchanges with marine water.

About half of the major species of benthic foraminifera assigned to the ecological categories (Table 4) are included in the species-list for Foram-AMBI of the Mediterranean Sea (Jorissen et al., 2018). Only three species are present in the similar list of the North-East Atlantic Ocean (Alve et al., 2016), which cover a broad spectrum of latitudes $\left(35^{\circ}\right.$ to $80^{\circ} \mathrm{N}$ ) and three species are also on the Gulf of Mexico list ( $\mathrm{O}^{\prime}$ Malley et al., 2021), an area with lower latitude and a different climate. The assignment to the ecological group of the species found in the Laizhou Bay coincides with that of the same species present in the Mediterranean Sea list. The only species that differs in ecological distribution is Elphidium limbatum, which in the present study shows III-order opportunistic behavior, while in the Mediterranean Sea it is classified as indifferent as Elphidium depressulum. This is an encouraging result because, although obtained through a small dataset, it shows a good coincidence with one of the two assignment lists of soft-bottom benthic foraminifera. Probably some characteristics of the Bohai Sea, such as its latitude and being a semi-enclosed marginal basin, make it more similar to the Mediterranean Sea than to the Atlantic Ocean. Of course, some species found in the Laizhou Bay are not included in the Mediterranean Sea list because they are characteristic of Chinese Seas and have a local or territorial distribution.

However, despite the differences highlighted, the foraminiferal assemblages in the Laizhou Bay are comparable with those in the Venice Lagoon, which has a confinement degree greater than the Adriatic Sea, and where Ammonia beccarii and Porosononion granosum are dominant in the biotopes with the lowest and highest ecological stress degree respectively (Albani et al., 2007).

The comparison between such distant marine areas does not simplify the resolution of possible taxonomic uncertainties, but, shows that the objective of assigning to each species a degree of ecological sensitivity and to each marine environment an index of environmental quality status is a viable route for the standardization of environmental monitoring.

\section{Conclusions}

The benthic foraminifera present in the surface sediments of the Laizhou Bay were analyzed for the assessment of their use in the biomonitoring both using the total assemblage to obtain the distribution of the foraminiferal biotopes and evaluating the attribution of the single species to a specific ecological group to obtain an ecological quality status index, the Foram-AMBI.

Among the 20 most abundant/significant species, six species were assigned to the sensitive ecological group, eight species to the indifferent ecological group, and the other species to the opportunists of second and third order.

The species present both in the Mediterranean Sea and in the Laizhou Bay appear to belong to the same ecological groups. This correspondence supports the assignment to the ecological categories obtained from our data set and, consequently, guarantees the reliability of the marine biotic index used here, the Foram-AMBI.

The zoning of foraminiferal biotopes reflects the mixing of marine and fluvial waters, with biotopes sterile or with few individuals and a low diversity index in the area close to the Yellow River Delta. The Foram-AMBI obtained for the analyzed samples agrees with the distribution of biotopes, indicating a better ecological quality status in the areas which are the furthest from the Yellow River mouth and confirming the validity of total assemblage for environmental monitoring.

The values of Foram-AMBI obtained through ecological assignment of benthic foraminifera species indicate a good ecological quality status for the analyzed samples. This result is consistent with the assessment of sediment quality based on acid-volatile sulphide and simultaneously extracted metal analyses carried out on the same samples, indicating heavy metals not or poorly bioavailable in the Laizhou Bay sediments.

\section{CRediT authorship contribution statement}

X.G and C.T. planned the sampling; X.G. and S.D. analyzed samples; S.D. and R.S.B. interpreted foraminiferal data and wrote the initial manuscript draft; L.T., R.S.B. and S.D. interpreted and discussed the 
results; S.D., R.S.B., X.G., C.T., and L.T. discussed, commented, and revised the manuscript and contributed to the paper's final version.

\section{Declaration of competing interest}

The authors declare that they have no known competing financial interests or personal relationships that could have appeared to influence the work reported in this paper.

\section{Acknowledgments}

This study was carried out under the support of the 2020-2022 Scientific Cooperation Program between the National Research Council of Italy and the Chinese Academy of Sciences, Project "Coastal system changes over the Anthropocene: Natural Vs Induced drivers".

\section{References}

Albani, A.D., Favero, V.M., Serandrei-Barbero, R., 1998. Distribution of sediment and benthic foraminifera in the Gulf of Venice, Italy. Estuar. Coast. Shelf Sci. 46 (2), 251-265. https://doi.org/10.1006/ecss.1997.0261.

Albani, A., Serandrei-Barbero, R., Donnici, S., 2007. Foraminifera as ecological indicators in the Lagoon of Venice, Italy. Ecol. Indic. 7, 239-253. https://doi.org/ 10.1016/j.ecolind.2006.01.003.

Alve, E., Murray, J.W., 1999. Marginal marine environments of the Skagerrak and Kattegat: a baseline study of living (stained) benthic foraminiferal ecology. Palaeogeogr. Palaeoclimatol. Palaeoecol. 146 (1-4), 171-193. https://doi.org/ 10.1016/S0031-0182(98)00131-X.

Alve, E., Lepland, A., Magnusson, J., Backer-Owe, K., 2009. Monitoring strategies for reestablishment of ecological reference conditions: possibilities and limitations. Mar. Pollut. Bull. 59 (8-12), 297-310. https://doi.org/10.1016/j. marpolbul.2009.08.011.

Alve, E., Korsun, S., Schönfeld, J., Dijkstra, N., Golikova, E., Hess, S., Husum, K., Panieri, G., 2016. Foram-AMBI: a sensitivity index based on benthic foraminiferal faunas from North-East Atlantic and Arctic fjords, continental shelves and slopes. Mar. Micropaleontol. 122, 1-12. https://doi.org/10.1016/j.marmicro.2015.11.001.

Borja, A., Franco, J., Pérez, V., 2000. A marine biotic index to establish the ecological quality of soft-bottom benthos within European estuarine and coastal environments. Mar. Pollut. Bull. 40 (12), 1100-1114. https://doi.org/10.1016/S0025-326X(00) 00061-8.

Borja, A., Franco, J., Muxika, I., 2003. Classification tools for marine ecological quality assessment: the usefulness of macrobenthic communities in an area affected by a submarine outfall. ICES CM 2, 1-10.

Buzas, M.A., Hayek, L.A.C., Reed, S.A., Jett, J.A., 2002. Foraminiferal densities over five years in the Indian River Lagoon, Florida: a model of pulsating patches. J. Foraminifer. Res. 32 (1), 68-92.

Donnici, S., Serandrei-Barbero, R., 2002. The benthic foraminiferal communities of the North Adriatic continental shelf. Mar. Micropaleontol. 44 (3-4), 93-123. https://doi. org/10.1016/S0377-8398(01)00043-3.

Donnici, S., Serandrei-Barbero, R., Taroni, G., 1997. Living benthic foraminifera in the Lagoon of Venice (Italy): population dynamics and its significance. Micropaleontology 440-454. https://doi.org/10.2307/1485933.

Donnici, S., Serandrei-Barbero, R., Bonardi, M., Sperle, M., 2012. Benthic foraminifera as proxies of pollution: the case of Guanabara Bay (Brazil). Mar. Pollut. Bull. 64, 2015-2028. https://doi.org/10.1016/j.marpolbul.2012.06.024.

Gao, X., Li, P., Chen, C.T.A., 2013. Assessment of sediment quality in two important areas of mariculture in the Bohai Sea and the northern Yellow Sea based on acid-volatile sulfide and simultaneously extracted metal results. Mar. Pollut. Bull. 72 (1), 281-288. https://doi.org/10.1016/j.marpolbul.2013.02.007.

Grall, J., Glémarec, M., 1997. Using biotic indices to estimate macrobenthic community perturbations in the Bay of Brest. Estuar. Coast. Shelf Sci. 44, 43-53. https://doi.org/ 10.1016/S0272-7714(97)80006-6.

Hammer, Ø., Harper, D.A.T., Ryan, P.D., 2001. PAST: paleontological statistics software package for education and data analysis. Palaeontol. Electron. 4 (1), 9 pp.

Hayward, B.W., Le Coze, F., Vachard, D., Gross, O., 2020. World foraminifera database. Accessed through: world register of marine species at: http://www.marinespecies. org.

Jorissen, F.J., de Stigter, H.C., Widmark, J.G., 1995. A conceptual model explaining benthic foraminiferal microhabitats. Mar. Micropaleontol. 26 (1-4), 3-15. https:// doi.org/10.1016/0377-8398(95)00047-X.

Jorissen, F., Nardelli, M.P., Almogi-Labin, A., Barras, C., Bergamin, L., Bicchi, E., El Katebe, A., Ferraro, L., McGann, M., Morigi, C., Romano, E., Sabbatini, A., Schweizer, M., Spezzaferri, S., 2018. Developing Foram-AMBI for biomonitoring in the Mediterranean: species assignments to ecological categories. Mar. Micropaleontol. 140, 33-45. https://doi.org/10.1016/j.marmicro.2017.12.006.

Lei, Y., Li, T., 2016. Atlas of Benthic Foraminifera From China Seas: The Bohai Sea and the Yellow Sea. Springer, 399 pp.

Lei, Y.L., Li, T.G., Bi, H., Cui, W.L., Song, W.P., Li, J.Y., Li, C.C., 2015. Responses of benthic foraminifera to the 2011 oil spill in the Bohai Sea, PR China. Mar. Pollut. Bull. 96 (1-2), 245-260. https://doi.org/10.1016/j.marpolbul.2015.05.020.
Lei, Y., Li, T., Nigam, R., Holzmann, M., Lyu, M., 2017a. Environmental significance of morphological variations in the foraminifer Ammonia aomoriensis (Asano, 1951) and its molecular identification: a study from the Yellow Sea and East China Sea, PR China. Palaeogeogr. Palaeoclimatol. Palaeoecol. 483, 49-57. https://doi.org/ 10.1016/j.palaeo.2016.05.010.

Lei, Y., Li, T., Jian, Z., Nigam, R., 2017b. Taxonomy and distribution of benthic foraminifera in an intertidal zone of the Yellow Sea, PR China: correlations with sediment temperature and salinity. Mar. Micropaleontol. 133, 1-20. https://doi.org/ 10.1016/j.marmicro.2017.04.005.

Li, X.Y., Shi, X.F., Cheng, Z.B., Qiao, S.Q., Wu, Y.H., Shi, F.D., 2010. Distribution of benthic foraminifera in surface sediments of the Laizhou bay, Bohai Sea and its environmental significance. Acta Micropalaeontol. Sin. 27 (1), 38-44.

Li, Z.Y., Liu, D.S., Long, H.Y., 2014. Living and dead benthic foraminifera assemblages in the Bohai and northern Yellow Seas: seasonal distributions and paleoenvironmental implications. Quat. Int. 349, 113-126. https://doi.org/10.1016/j. quaint.2014.05.019.

Li, T., Li, X., Zhong, H., Yang, C., Sun, G., Luo, W., 2015. Distribution of trace metals and the benthic foraminiferal assemblage as a characterization of the environment in the north Minjiang River Estuary (Fujian, China). Mar. Pollut. Bull. 90 (1-2), 227-241. https://doi.org/10.1016/j.marpolbul.2014.10.047.

Li, B., Li, X., Bouma, T.J., Soissons, L.M., Cozzoli, F., Wang, Q., Zhou, Z., Chen, L., 2017. Analysis of macrobenthic assemblages and ecological health of Yellow River Delta, China, using AMBI \& M-AMBI assessment method. Mar. Pollut. Bull. 2017 https:// doi.org/10.1016/j.marpolbul.2017.03.044.

Loeblich, A.R., Tappan, H., 1987. Foraminiferal Genera and Their Classification. Van Nostrand Reinhold Company, New York, p. 970.

Ni, D., Zhang, Z., Liu, X., 2019. Benthic ecological quality assessment of the Bohai Sea, China using marine biotic indices. Mar. Pollut. Bull. 142, 457-464. https://doi.org/ 10.1016/j.marpolbul.2019.03.055.

O’Malley, B.J., Schwing, P.T., Martínez-Colón, M., Spezzaferri, S., Machain-Castillo, M. L., Larson, R.A., Hollander, D.J., 2021. Development of a benthic foraminifera based marine biotic 2 (Foram-AMBI) for the Gulf of Mexico: a decision support tool. Ecol. Indic. 120, 106916. https://doi.org/10.1016/j.ecolind.2020.106916.

Qiao, S., Shi, X., Zhu, A., Liu, Y., Bi, N., Fang, X., Yang, G., 2010. Distribution and transport of suspended sediments off the Yellow River (Huanghe) mouth and the nearby Bohai Sea. Estuar. Coast. Shelf Sci. 86 (3), 337-344. https://doi.org/ 10.1016/j.ecss.2009.07.019.

Schmiedl, G., Mackensen, A., Müller, P.J., 1997. Recent benthic foraminifera from the eastern South Atlantic Ocean: dependence on food supply and water masses. Mar. Micropaleontol. 32 (3-4), 249-287. https://doi.org/10.1016/S0377-8398(97) 00023-6.

Scott, D.B., Tobin, R., Williamson, M., Medioli, F.S., Latimer, J.S., Boothman, W.A., Asioli, A., Haury, V., 2005. Pollution monitoring in two north American estuaries: historical reconstructions using benthic foraminifera. J. Foraminifer. Res. 35, 65-82. https://doi.org/10.2113/35.1.65.

Serandrei-Barbero, R., Carbognin, L., Taroni, G., Cova, E., 1999. Distribution of recent benthic foraminifera in the southern basin of the Venice lagoon (Italy): statistical evaluation of taxa significance. Micropaleontology 45, 99-111. https://doi.org/ $10.2307 / 1486205$.

Serandrei-Barbero, R., Morisieri, M., Carbognin, L., Donnici, S., 2003. An inner shelf foraminiferal fauna and its response to environmental processes (Adriatic Sea, Italy). Rev. Esp. Micropaleontol. 35 (2), 1-24.

Serandrei-Barbero, R., Donnici, S., Madricardo, F., 2011. Supratidal foraminifera as ecological indicators in anthropically modified wetlands (Lagoon of Venice, Italy). Ecol. Eng. 37 (8), 1140-1148. https://doi.org/10.1016/j.ecoleng.2011.02.009.

Smart, C.W., Gooday, A.J., 1997. Recent benthic foraminifera in the abyssal Northeast Atlantic Ocean; relation to phytodetrital inputs. J. Foraminifer. Res. 27 (2), 85-92. https://doi.org/10.2113/gsjfr.27.2.85.

Wang, H., Bi, N., Saito, Y., Wang, Y., Sun, X., Zhang, J., Yang, Z., 2010. Recent changes in sediment delivery by the Huanghe (Yellow River) to the sea: causes and environmental implications in its estuary. J. Hydrol. 391 (3-4), 302-313. https:// doi.org/10.1016/j.jhydrol.2010.07.030.

Wang, F., Gao, M., Liu, J., Pei, S., Li, C., Mei, X., Yang, S., 2016. Distribution and environmental significance of live and dead benthic foraminiferal assemblages in surface sediments of Laizhou Bay, Bohai Sea. Mar. Micropaleontol. 123, 1-14. https://doi.org/10.1016/j.marmicro.2015.12.006.

Zhan, C., Wang, Q., Cui, B., Zeng, L., Dong, C., Li, X., Liu, X., 2020. The morphodynamic difference in the western and southern coasts of Laizhou Bay: responses to the Yellow River estuary evolution in the recent 60 years. Glob. Planet. Chang. 187, 103138. https://doi.org/10.1016/j.gloplacha.2020.103138.

Zhang, J., Gao, X., 2015. Heavy metals in surface sediments of the intertidal Laizhou Bay, Bohai Sea, China: distributions, sources and contamination assessment. Mar. Pollut. Bull. 98 (1-2), 320-327. https://doi.org/10.1016/j.marpolbul.2015.06.035.

Zheng, S., 1990. Foraminiferal faunal trends and assemblages of the Bohai Sea, Huanghai Sea and East China Sea. Bull. Mar. Sci. 47 (1), 192-212.

Zhou, L., Liu, J., Saito, Y., Gao, M., Diao, S., Qiu, J., Pei, S., 2016. Modern sediment characteristics and accumulation rates from the delta front to prodelta of the Yellow River (Huanghe). Geo-Mar. Lett. 36, 247-258. https://doi.org/10.1007/s00367 016-0442-x.

Zhuang, W., Gao, X., 2014. Integrated assessment of heavy metal pollution in the surface sediments of the Laizhou Bay and the coastal waters of the Zhangzi Island, China: comparison among typical marine sediment quality indices. PLoS One 9 (4). https:// doi.org/10.1371/journal.pone.0094145. 